\title{
Sociolinguistic Dimension of the Glutonia Phenomenon
}

\author{
Iryna Masliaieva ${ }^{1, *}$ \\ ${ }^{1}$ Kryvyi Rih State Pedagogical University, Ukraine \\ *Corresponding author.Email: masliaievairyna@gmail.com
}

\begin{abstract}
The article deals with the impact of globalization processes on the current state of the Ukrainian-speaking phenomenon of gluten. Also we investigated the phenomenon of gluten through the prism of sociocultural and sociolinguistic aspects based on the identification of linguistic and cultural specifics of gluten names (names of food) in literary text. In addition, a sociolinguistic dimension of axiological parameters of gluten`s fragments of discourse was described out with the involvement of students of philology department at Kryvyi Rih State Pedagogical University. We analyzed the results of the questionnaire and discovered the main problems of the functioning of the gluten phenomenon in the global world in general and in the Ukrainian-speaking linguistic community in particular.
\end{abstract}

Keywords: gluttony, sociolinguistics, globalization, gluten name (names of food), linguoculture.

\section{1. ВСТУП}

Сьогодні сучасний світовий простір неможливо уявити без культурної інтеграції й уніфікації, які, своєю чергою, уможливлюють як прогрес, так і регрес культурного (згодом економічного) розвитку кожного цивілізованого суспільства. Наслідком успішної реалізації відповідних процесів є порозуміння 3 іншими лінгвокультурними спільнотами, натомість негативний вплив засвідчує втрату самобутності тією чи тією етнокультурою, за якою закріплюється так зване значення “меншовартості".

Варто наголосити на тому, що окреслена проблема стосується будь-якої соціальної сфери, зокрема й сфери харчування, оскільки їжа не просто підтримує матеріальність і тілесність людини як живої істоти, але й супроводжує іiі повсякденність і соціалізацію [1]; у мистецтві приготування й споживання їжі, що є однією 3 найдавніших сфер людської діяльності, виявляються специфічні національні, соціальні, економічні, етичні й естетичні норми поведінки [2]. В умовах глобалізації постає нагальна потреба у висвітленні взаємодії “чужого” й “свого” під час формування культурних та державних орієнтирів, адже запозичення певних цінностей у жодному разі не повинно знівелювати національних особливостей окремої етноспільноти [3].

\section{2. СУЧАСНІ НАУКОВІ ОРІЕНТИРИ}

Відповідна проблематика змінює вектор вітчизняних гуманітарних наук, розширює потенційні можливості подальших розвідок, спонукає до модерного прочитання сучасного світу. Фіксуємо появу міждисциплінарних лінгвістичних царин на кшталт соціолінгвістика (Л. Ставицька, О. Олексюк, Л. Білоконенко), психолінгвістика (Л. Засєкіна, С. Куранова, К. Марчук, Л. Калмикова), етнолінгвістика (Н. Шарманова, В. Жайворонок, Л. Савченко), соціопсихолінгвістика (О. Антонюк, Л. Паламар, М. Філон), які покликані дослідити соціолінгвістичні аспекти оволодіння мовою; міжнародний досвід мовного планування; комунікативні, етноментальні, соціопсихологічні аспекти мовного існування; ідіолект певної нації; соціокомунікативні аспекти репрезентації; мовний побут сучасного світу та ін.. Найбільш важливим напрямом зазначених студій $є$ апеляція до антропоцентричної парадигми, у вивченні якої натрапляємо на посилену увагу до соціальних, вікових, культурних чинників формування мовної 
особистості за допомогою аналізу мови й мовної поведінки дітей та дорослих різних лінгвокультурних спільнот [4]. Окрім того, заслуговує на належну увагу й порівняно нова наука, поіменована в аналізованій літературі як еколінгвістика, або лінгвоекологія (Б. Ажнюк, О. Сербенська, С. Клочко, Ж. Колоїз), що має на меті з'ясувати природні, соціальні й культурні умови, необхідні для збереження національних мов як засобів національної ідентичності в аспекті глобалізації [3].

Неабиякого значення в цьому аспекті набуває студіювання феномену глютонії в українськомовному соціумі, оскільки на становлення української кухні загалом (кулінарної терміносистеми зокрема) впливали і продовжують впливати чинники як внутрішньосуспільного, так і міжнародного рівнів [6, p. 403]. Одним із грунтовних досліджень сучасності можна вважати дисертаційну працю соціолога В. Ніколенка, який висвітлив гастрономічні детермінанти суспільного життя крізь призму соціологічного виміру. Однак в умовах міжкультурної комунікації повсякчас з'являються нові страви i, відповідно, їх найменування, які швидко адаптуються на українськомовному грунті, а самі страви так само можуть претендувати на статус національних, доповнювати й увиразнювати когнітосферу глютонії. Саме тому мета нашої статті дослідження явища глютонії як соціолінгвістичного феномену (на основі проведення анкетування).

\section{1. Вплив процесів глобалізації на феномен глютоніі}

Як і багато років тому, сучасний простір переживає епоху сталого розвитку: фіксуємо безперервність економічної діяльності, промислових та наукових відкриттів, які зумовлюють розширення соціальних орієнтирів $\mathrm{i}$ актуалізують низку новітніх розвідок. Усе це безпосередньо впливає й на формування українського глютонійного коду. Стосовно цього слушною $є$ думка А. Муратової - дослідниця наголошує на тому, що їжа супроводжує всі важливі, значущі події в житті людини: народження, свята, проводи, зустрічі, весілля, входини тощо, навіть короткочасні повсякденні події - до сусідки на хвилинку - й офіційні заходи, урочистості, коли, здавалося б, без їі можна обійтися (дипломатичні прийоми, випускний бал тощо), супроводжуються хоч би символічною трапезою [7]. Це $є$ цілком закономірним, адже українській (і не тільки) культурі харчування властиві своєрідні звичаї, пов'язані 3 приготуванням, сервіруванням страв, певними ритуальними обрядами, обмеженнями й заборонами, смаковими уподобаннями у споживанні святкових або повсякденних продуктів харчування та ін. Так, не можна не згадати власне національні українські страви, які стали улюбленими не лише на теренах України, але й далеко за iї межами. До таких зазвичай уналежнюють вироби з тіста: вареники, галушки, коржі й т. ін. Неабияке значення в українській сакральній традиції має хліб. Як зазначає В. Ніколенко, у центрі високого семантичного поля української гастрономії назавжди залишився хліб. У соціальному сенсі наявність хліба для селян i бідних верств населення означала можливість жити, а тому хліб - найвиразніший, найпопулярніший, найбільш значущий атрибут слов'янського застілля, зокрема українського [6, p. 334].

Сьогодні натрапляємо на значну кількість глютонійних аналогів в інших етнокультурних спільнотах у всьому світі: чимала частина схожих національних страв і напоїв усталилася в мовній і культурній канві того чи того етносу, стала символічною для свого народу, оскільки відповідні страви являють собою так званий світовий бренд, який глобалізоване суспільство сприймає здебільшого позитивно. Наприклад, такі назви страв, як борщ, піца, паста, суші або напоїв - кава, мохіто, пиво, вино, горілка, коньяк, стали промовистими символами, що набули загальновизнаної популярності в усьому світі. А відтак, можна стверджувати, що глютонійний вимір будь-якої лінгвоспільноти, нації - це невід'ємний складник іiі культурного доробку, своєрідне віддзеркалення історичного досвіду, певних форм прояву масової свідомості, соціально-економічних благ.

Глютонійна культура є яскравим виразником сучасних соціальних практик, тісно пов'язаних із процесом харчування та загальною системою того чи того етнокультурного виробництва. Цілком закономірним $є$ те, що в останні роки XXI століття на світову арену виходять нові харчові бренди, які модифікують міжнародні торгові відносини між представниками інших країн, а це, своєю чергою, стирає межі між кухнями й глютонійними уподобаннями різних народів, продукує багато революційних змін у новітніх системах харчування [6, p. 363]. Саме тому сьогодні глютонійний вимір пересічної людини 
не має жодних прив'язок до місця, де вона народилася, адже навіть екзотичні продукти, що раніше вважалися недоступними, можна придбати чи не в будь-якому куточку світу. Дослідники говорять і про нівеляцію меж між щоденними й святковими наїдками (передовсім це стосується заможних верств населення), про відкидання сезонності споживання їжі (за часів глобалізації не треба чекати літа, аби скуштувати кавун, диню та ін. “літні” смаколики).

Попри активне укорінення культурної інтеграції, взаємозв'язок традицій харчування 3 багатьма сторонами соціокультурного життя певного етносу не зникає, а навпаки, простежується в доволі неординарних формах: українські засоби масової інформації маніфестують культ їжі за допомогою різноманітних форм трансляції - реклами; кулінарних реаліті-шоу; майстер-класів, у яких беруть участь зірки шоу-бізнесу; традиційних кулінарних програм з елементами світських бесід; кулінарних змагань (спрямовані на те, щоб навчити телеглядачів оцінити якість продуктів i послуг у закладах громадського харчування); нових форматів репрезентації гастрономічного туризму: поєднання тревел і кулінарного шоу (до зазначених вище різновидів можна уналежнити такі програми, як “Мастер Шеф”, “Звана вечеря”, “Сніданок з 1+1”, “Ревізор”, “Знак якості”, “Їжа Дурнєва”, “ЛавЛавСаr”, “Світ навиворіт”, “Орел і Решка”, “Їже, я люблю тебе”, та ін.). Окрім того, майже в кожному широковідомому виданні натрапляємо на сторінки 3 рецептами, сучасні кулінарні лайфхаки (зазвичай це авторські рекомендації відомих людей). Варто, очевидно, пояснити таку бурхливу зацікавленість феноменом глютонії: передовсім це пов'язано із впливом вестернізації (перехід від власної традиційної системи цінностей до системи американських чи західноєвропейських цінностей [3]) - Захід диктує моду здорового способу життя та розмаїття кулінарних традицій інших етнокультур. Відповідні тенденції популяризуються й за допомогою так званого гастрономічного туризму. Інша причина повернення до іманентних цінностей людини, які знаходять різні форми власного прояву саме у глютонійному просторі [6, p. 368].

\section{2. Соціолінгвістичні виклики сьогодення}

Своєрідне втілення вестернізації знаходимо й на сторінках сучасної української літератури, де особливої актуальності набувають твори кулінарної тематики [5]. Так, подальше дослідження грунтуватиметься на фактичному матеріалі книги Ірен Роздобудько “Мандрівки без сенсу i моралі”, оскільки відповідний текст містить значну кількість іншокультурних глютонічних найменувань, що маніфестують взаємозбагачення культур. Відтак, наше завдання полягає у проведенні соціолінгвістичного анкетування для того, аби з'ясувати правомірність і доцільність уживання тих чи тих іншокультурних номенів не лише у сучасній прозі, але й безпосередньо в українській мові, окреслити вплив глобалізаційних процесів, описати їхні переваги та недоліки за допомогою відповідей респондентів.

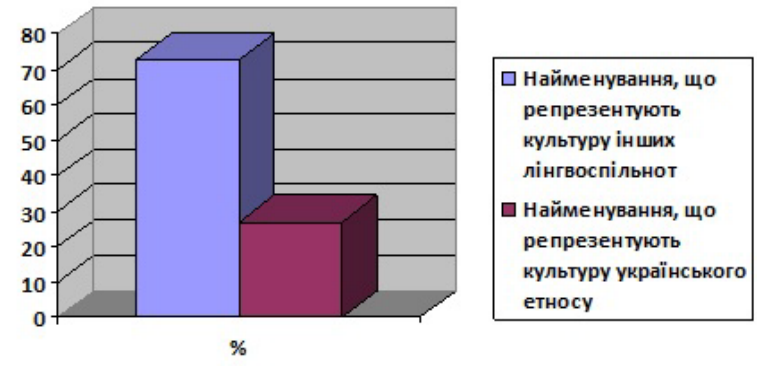

Рисунок 1 Лінгвокультурні параметри глютонійних найменувань

До соціолінгвістичного експерименту були залучені студенти Криворізького державного педагогічного університету факультету української філології, відповіді яких допомогли нам дослідити сприйняття мовленнєвих фактів, отримати достовірну інформацію про знання / незнання певних глютонічних фрагментів, уміння / невміння витлумачувати ті чи ті глютонічні найменування i, відповідно, послуговуватися ними в означеній сфері комунікації. Задля цього ми скористалися анкетуванням, що є доцільним під час розв'язання лінгвістичних проблем, які апелюють до колективної інтуїції носіїв мови. Окрім того, саме анкетування дало змогу встановити ступінь сприйняття пропонованих фрагментів глютонії, тих чи тих глютонійних найменувань, що маніфестують чи то національну глютонійну культуру, чи то культуру інших народів; визначити, наскільки точно респонденти можуть ідентифікувати значення тих чи тих одиниць, продемонструвати свою ерудицію, знання, інтелектуальний рівень. 


\section{3. ІНТЕРПРЕТАЦІЯ РЕЗУЛЬТАТІВ АНКЕТУВАННЯ}

Анкетування проводилося анонімно, ним було охоплено сто респондентів, віком від 17 до 30 років. У запропонованій анкеті респонденти мали вказати свій вік, стать, факультет, форму навчання й відповісти на 2 блоки запитань. Перший блок передбачав зокрема й загальні питання на зразок: 1) Чи знаєте Ви значення слова “глютонії? Чи зможете його пояснити, якщо матимете підказку?; 2) Чи читали Ви твори сучасної української літератури, які уналежнюють до так званої «кулінарної прози»? Чи хотіли б прочитати? А якщо читали, то чи рекомендували б його прочитати своїм знайомим?; 3) Деякі твори засвідчують велику кількість іншомовних глютонійних назв. Чи чули ви такі назви, знаєте їх значення й чи послуговуєтеся відповідними словами?; 4) У таких творах наявні й іншомовні назви, які вже устаткувалися мовним узусом. Чи чули ви такі назви, знаєте їх значення й послуговуєтеся відповідними словами? 5) Чи подобається Вам те, що автори зловживають іншомовними словами у своїх творах? 6) Чи варто заміняти іншомовні слова українськомовними відповідниками, якщо $\epsilon$ така змога?

Другий блок мав на меті більшою мірою виявити ціннісні орієнтири й модель комунікативної поведінки респондентів, які мали обрати, як і в першому разі, один із чотирьох запропонованих варіантів відповідей: 1) Чи чули ви слова, які використовуються для позначення різних національних страв (касатела, калалаатикко, кофта, айя, гулаб-джамун, клемчаудер), і чи знаєте їх значення?; 2) Усі слова $є$ назвами продуктів харчування (жуна, лічі, шкампія, броде, nappe). Чи всі назви ви чули і чи всі можете витлумачити?; 3) Усі подані слова $є$ назвами продуктів харчування (гамбургер, сандвіч, чіпси, пудинг). Чи всі назви ви чули, розумієте i послуговуєтеся відповідними словами?; 4) Усі подані слова є назвами продуктів харчування (кугл, хумус, гуава, лангуст, кнедлики, барабулька, гальба). Чи всі назви ви чули, розумієте i послуговуєтеся відповідними словами?; 5) Сьогодні світові кулінарні традиції заполонили українськомовний простір (зокрема 3МІ, книги, кулінарні гіди демонструють активну популяризацію “заморських” уподобань). Як Ви вважаєте, чи зможуть вони витіснити вітчизняні реалії?; 6) Чи погоджуєтеся Ви з думкою про те, що наразі варто відроджувати вітчизняні кулінарні традиції?

Пропонуємо ознайомитися з результатами, які представлено за двома блоками.

\section{Відповіді респондентів на запитання І-го блоку}

1. Чи знаєте Ви значення слова “глютонія”? Чи зможете його пояснити, якщо матимете підказку?

а) знаю і правильно витлумачено (16\%);

б) знаю і неправильно витлумачено (42\%);

в) не знаю і знати не хочу (10\%);

г) не знаю, але скористаюся підказкою (32\%).

2) Чи читали Ви твори сучасної української літератури, які уналежнюють до так званої “кулінарної прози”? Чи хотіли б прочитати? А якщо читали, то чи рекомендували б його прочитати своїм знайомим?

а) читав (-ла) і рекомендую прочитати (6\%);

б) читав (-ла) i не рекомендую прочитати $(74 \%)$;

в) не читав (-ла), але хочу прочитати (18\%);

г) не читав (-ла) і не хочу прочитати (2\%).

3) Деякі твори засвідчують велику кількість іншомовних глютонійних назв. Чи чули ви такі назви, знаєте їх значення й чи послуговуєтеся відповідними словами?

a) чув (-ла), знаю $\quad$ (i правильно прокоментовано) і послуговуюся (6\%);

б) чув (-ла), знаю $\quad$ (i правильно прокоментовано), але не послуговуюся (18\%);

в) чув (-ла), але не знаю й не послуговуюся $(32 \%)$;

г) не чув (-ла), не знаю й не послуговуюся (44\%).

4) У таких творах наявні й іншомовні назви, які вже устаткувалися мовним узусом. Чи чули ви такі назви, знаєте їх значення й послуговуєтеся відповідними словами?

a) чув (-ла), знаю (i правильно прокоментовано) і послуговуюся (89\%);

б) чув (-ла), знаю (i правильно прокоментовано), але не послуговуюся (8\%);

в) чув (-ла), але не знаю й не послуговуюся $(3 \%)$; 
г) не чув (-ла), не знаю й не послуговуюся ( $0 \%)$.

5) Чи подобається Вам те, що автори зловживають іншомовними словами у своїх творах?

а) так (49\%);

б) ні $(39 \%)$;

в) категорично ні (11\%);

г) частково (1\%).

6) Чи варто заміняти іншомовні слова українськомовними відповідниками, якщо $є$ така змога?

а) так $(76 \%)$;

б) ні (6\%);

в) категорично ні (1\%);

г) частково (17\%).

\section{Відповіді респондентів на запитання ІІ-го блоку}

1) Чи чули ви слова, які використовуються для позначення різних національних страв (касатела, ка-лалаатикко, кофта, айя, гулаб-джамун, клемчаудер), і чи знаєте їх значення?

a) чув (-ла), знаю (i правильно прокоментовано) (0\%);

б) чув $\quad$ (-ла), знаю $\quad$ (неправильно прокоментовано) $(2 \%)$;

в) чув (-ла), але не знаю (6\%);

г) не чув (-ла), не знаю (92\%).

2) Усі слова є назвами продуктів харчування (жуна, лічі, шкампія, броде, парфе). Чи всі назви ви чули і чи всі можете витлумачити?

а) чув (-ла), зможу (i всі правильно витлумачено) (0\%);

б) чув (-ла), зможу (половину правильно витлумачено) $(0 \%)$;

в) чув (-ла), але не знаю (13\%);

г) не чув (-ла), не знаю (87\%).

3) Усі подані слова $є$ назвами продуктів харчування (гамбургер, сандвіч, чіпси, пудинг). Чи всі назви ви чули, розумієте і послуговуєтеся відповідними словами?

a) чув (-ла), знаю (i правильно прокоментовано) і послуговуюся (97\%); б) чув (-ла), знаю (i правильно прокоментовано), частково послуговуюся (3\%);

в) чув (-ла), але не знаю й не послуговуюся $(0 \%)$;

г) не чув (-ла), не знаю й не послуговуюся $(0 \%)$.

4) Усі подані слова $\epsilon$ назвами продуктів харчування (кугл, хумус, гуава, лангуст, кнедлики, барабулька). Чи всі назви ви чули, розумієте і послуговуєтеся відповідними словами?

a) чув (-ла), знаю (i правильно прокоментовано) і послуговуюся (0\%);

б) чув (-ла), знаю (i правильно прокоментовано), частково послуговуюся (2\%);

в) чув (-ла), але не знаю й не послуговуюся $(37 \%)$;

г) не чув (-ла), не знаю й не послуговуюся $(61 \%)$.

5) Сьогодні світові кулінарні традиції заполонили українськомовний простір (зокрема 3МI, книги, кулінарні гіди демонструють активну популяризацію “заморських” уподобань). Як Ви вважаєте, чи зможуть вони витіснити вітчизняні реалії?

а) так $(38 \%)$;

б) ні (21\%);

в) категорично ні (8\%);

г) частково $(33 \%)$;

6) Чи погоджуєтеся Ви з думкою про те, що наразі варто відроджувати вітчизняні кулінарні традиції?

a) так $(87 \%)$;

б) ні $(6 \%)$;

в) категорично ні (0\%);

г) частково (7\%).

Опрацювання результатів анкетування грунтувалося на використанні методу групування мовного матеріалу (диференціація глютонійних найменувань за певними групами) та описового методу (установлення певних закономірностей у сприйнятті / несприйнятті досліджуваних явищ). Учасники опитування продемонстрували здебільшого незнання (а то й небажання знати!) лінгвокультурної специфіки глютонічних найменувань, що побутують в сучасному українськомовному просторі. Респонденти 
невдоволені тим, що в умовах вестернізації та глобалізації уживання іншомовних слів загалом та найменувань, які висвітлюють глютонійні орієнтири, зокрема набуває неабиякої популярності - це ускладнює як і процес сприйняття інформації, так і процес комунікації. Студенти-філологи погоджуються 3 думкою про те, що певні глютонійні фрагменти вже усталилися мовним узусом, а тому не потребують певних пошукових дій. Очевидно, це й уможливлює успішну міжкультурну комунікацію та взаємозбагачення культур. Але респонденти розуміють, що такий перебіг подій не завжди продукує позитивні наслідки, а відтак, варто, на їхній погляд, замінювати іншомовні відповідники українськими (якщо є змога).

Беззаперечним є те, що нині спостерігається активне вживання глютонійних найменувань чужих культур, що заполонили українськомовний простір. Схематично це має такий вигляд:
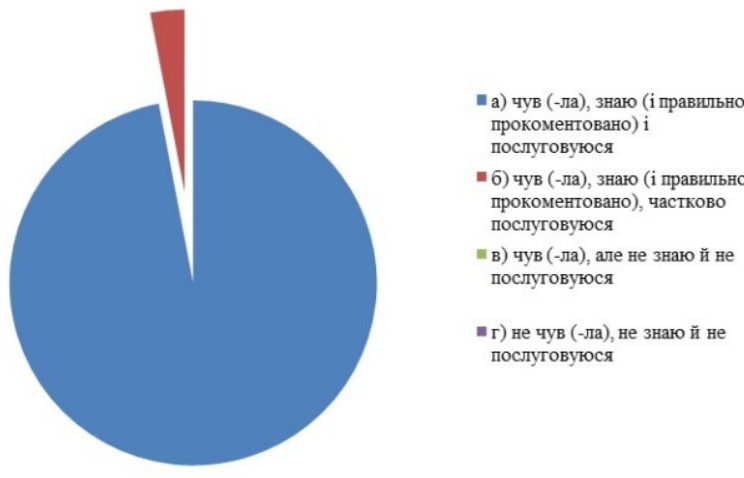

Рисунок 2 Аксіологічний вимір параметрів іншокультурних фрагментів феномену глютонії в мовленні респондентів-філологів

3 огляду на стрімкий процес уніфікації глобального світу наявна загроза витіснення національної глютонійної культури, яка в майбутньому зможе i не зберегти своєї самобутності. Однак втішним $є$ те, що значний відсоток студентів усе-таки позитивно сприймає національні кулінарні традиції й уболіває за їхнє збереження й відновлення.

\section{4. ВИСНОВКИ}

Феномен глютонії $є$ багатоаспектним суспільним явищем, яке передбачає поєднання низки фреймів: евристичний (уможливлюю вивчення специфіки організації людського світу), знаковий, або символічний (описує повсякденні процеси суспільного життя, моделі соціальної взаємодіï) та ціннісний (дає змогу пізнати міжособистісні та міжгрупові етнокультурні домінанти). Окрім того, глютонійний феномен реалізує комунікативну стратегію соціальних відносин на світовому рівні. Варто наголосити на тому, що українськомовний простір під впливом явища глютонії зазнав деяких модифікацій: репертуар української гастрономії не лише удосконалює власну неповторність, самобутність, але й розширює культурні межі, про що свідчить і проведене нами опитування.

Соціолінгвістичний вимір аксіологічних параметрів фрагментів глютонії дає змогу узагальнити: респонденти здебільшого не розуміють лінгвокультурної специфіки глютонійних найменувань, що побутують в сучасному українськомовному просторі. А деякі іншокультурні найменування викликають “культурний шок”, оскільки, потрапивши різними шляхами в український соціум, вони поки що не змогли повністю адаптуватися, а подекуди й не приймаються, а той узагалі відштовхуються національною лінгвоспільнотою. Насамкінець анкетування продемонструвало те, що глютонійна культура сучасного українського суспільства потребує модернізації і трансформації за допомогою відновлення шанобливого ставлення до власних традицій.

\section{ВНECOK АВTOPA}

У межах запропонованої статті окреслено вплив глобалізаційних процесів на сучасний стан українськомовного феномену глютонії, досліджено явище глютонії крізь призму соціокультурного й соціолінгвістичного аспектів на основі виявлення лінгвокультурної специфіки глютонійних найменувань у літературнохудожньому тексті. Окрім того, здійснено соціолінгвістичний вимір аксіологічних параметрів фрагментів глютонійного дискурсу із залученням студентів-філологів Криворізького державного педагогічного університету. Результати анкетування показали подвійні стандарти функціонування феномену глютонії в сучасному глобалізаційному просторі: $з$ одного боку, лінгвокультурний код українськомовного пласту кулінарних найменувань перенасичений іншовізмами, а з іншого - це вносить своєрідний елемент новизни, що зацікавлює не тільки респондентів, але й пересічних мовців. 


\section{REFERENCES}

[1] N.A. Ustinova, Pischevoy kod kak simvolizatsiya pischevoy traditsii (na materiale govorov Srednego Priobya) [Food code as symbolization of the food tradition (in the Middle Priobiya speaking material)], Vestnik Tomskogo gosudarstvennogo universiteta 333 (2010) 28-31.

[2] E.A. Cherednikova, Aksiologicheskie harakteristiki gastronomicheskogo diskursa [Axiological characteristics of gastronomic discourse], Vestnik Moskovskogo gosudarstvennogo universiteta 5 (2011) 78-82.

[3] Zh.V. Koloiz, Ekolingvalnyj balans v umovax globalizaciyi [Ecolingual balance in the context of globalization], in: Materialy dopovidej, pryurochenyh 90-richchyu Kryvorizkogo derzhavnogo pedagogichnogo universytetu, vygoloshenyh u ramkax VI Mizhnarodnoyi naukovoyi konferenciyi "Ukrayinska mova sered inshyh slovyanskyh: etnologichni ta gramatychni parametry", Kryvyi Rih, 2020, pp. $75-76$.

[4] R. Cavanaugh, C. Kathleen, A. Jourdan, What Words Bring to the Table: The Linguistic Anthropological Toolkit as Applied to the Study of Food, Journal of Linguistic Anthropology 24 (2014) 84-97.

[5] V.I. Dmytrenko, Hastronomichnyi dyskurs suchasnoi zhinochoi prozy [Gastronomic discourse of modern women's prose], Naukovyi visnyk Mykolaivskoho derzhavnoho universytetu imeni Vasylia Sukhomlynskoho 2 (16) (2015) 77-80.

[6] V.V. Nikolenko, Hastronomichni determinanty suspilnoho zhyttia: sotsiolohichnyi vymir [Gastronomic determinants of social life: a sociological dimension], Dnipropetrovsk, 2015.

[7] A.S. Muratova, Edenie kak vyirazhenie kulturyi [Eating as an expression of culture], Moskovskiy zhurnal 5 (1992) 178. 